\title{
Those who are forgotten: The existence of Ketoprak Rukun Karya in Sumenep Madura, 1976-2000s
}

\author{
J. Sayono*, R. Ridhoi, N. Jauhari, I.H. Al Siddiq, A. Prasetyawan \& N.A.D. Restanti \\ Universitas Negeri Malang, Malang, Indonesia
}

\begin{abstract}
Since the mid-20th century, the traditional art of ketoprak on Madura Island, particularly in Sumenep Regency, has shown its existence. There are two well-known ketoprak in Madura, namely Rukun Famili and Rukun Karya. However, the original Sumenep ketoprak art seems absent from Indonesian and Maduran historiography. This paper aims to explain the history of traditional theater arts in Madura, especially the Rukun Karya ketoprak located in Sumenep. This paper uses the historical method by conducting a careful reading of several archival sources and interviews. The results of this study indicate that although Ketoprak Rukun Karya had existed since 1976, the people of Sumenep (urban) do not know and like this art. Additionally, in the Sumenep area, the Rukun Karya archipelago has become a popular and luxurious entertainment for the people. This is due to the rapid modernization of urban society and the erosion of local artistic values.
\end{abstract}

Keywords: Ketoprak, Rukun Karya, Sumenep, Madura Island

\section{INTRODUCTION}

Indonesia's wealth lies not only in its natural and human resources but also in its cultural diversity, which must be preserved. Each Indonesian region has a variety of arts. These arts are usually passed down from generation to generation so that they can still be enjoyed by the younger generation (Weintraub 2010; Ridhoi 2018; Azali 2012). In relation to the traditional theater arts, Sumenep Regency is one of Madura's areas that still has one of the traditional theater arts, namely ketoprak. The local community is more familiar with this ketoprak as loddrok. Since around the middle of the 20th century, several ketoprak have been born on Madura's island to be precise in the area of Sumenep Regency.

The famous ketoprak in Madura is the ketoprak Rukun Family and Rukun Karya. Both ketoprak have been around for a long time and are still in existence today. Similar to the general ludruk and ketoprak, the ketoprak in Madura also take stories from everyday life and from history and legends. Ketoprak Madura also has a director or puppeteer to arrange the storyline during the show (Imron 2020). This article aims to investigate the development of traditional theater arts in modern times like today.

Several previous studies discuss traditional theater arts in East Java. One of them is written by Samidi, entitled Traditional Theater in Surabaya 1950-1965: Community Relations and Art Troops. This article describes the development of traditional theater in the mid-20th century in Surabaya. Traditional theater performances in Surabaya are closely related to the relationship between the utterance of solidarity with the community (Samidi 2006). The article's goal is to find out the relationship between the community or the audience and a group of traditional theater players in Surabaya in the mid-20th century.

\footnotetext{
*Corresponding author: joko.sayono.fis@um.ac.id
} 
In addition, there are also articles that discuss the development of ketoprak; one article is written by Saptomo, entitled History, and Development of Ketoprak in Modern Society Life. The article describes the development of ketoprak, which has changed according to the conditions of the community (Cohen 2013). According to Saptomo (1996), the community's development and attention to the art of ketoprak theater was only felt in the 1950s. From those several previous studies, there are very few researches that focus on the history and development of the Rukun Karya ketoprak in Sumenep. The history of traditional theater arts must be investigated deeply. This is because the development of the conventional theater arts era needs preservation to be enjoyed by young people and gain more attention from the Indonesian people.

\section{METHODS}

In writing this article, researchers used historical research methods by utilizing sources such as interviews, articles, and so forth. The historical research method has five stages, namely topic selection, source collection (heuristics), source verification, interpretation and writing. The topic chosen by the researcher was a research plan that had been prepared beforehand, namely by selecting the topic of art history, especially the art of ketoprak in Sumenep Regency, Madura, East Java. After determining the topic, the researcher collected sources by collecting news about ketoprak performances in Madura, books that discussed ketoprak or traditional theater arts and interviews with ketoprak figures in Rukun Karya in Sumenep. After that, source verification was completed by looking at the credibility of the sources obtained. The sources were classified into two categories, namely primary sources or secondary sources. After verifying the source, the interpretation was carried out by analyzing the obtained sources and continued to the source criticism stage. Finally, a writing or historiography process regarding the history of the traditional theater was conducted. It discussed the development of the Rukun Karya ketoprak in Sumenep in the 2000s.

\section{RESULTS AND DISCUSSION}

\subsection{Development of traditional theater arts}

Theater is an art that has long been developing in Indonesia. It is divided into three types widely known by Indonesian people: traditional theater, transitional theater and modern theater (Peters 2016). The traditional theater is a theater that was born from, by, and for the traditions of a particular society (Heryanto 1982). The traditional theater in each region is different. The term traditional theater is part of a regional art form that was born and developed in certain communities and those who live in certain areas (Zaini 2015). One example is the traditional theater in East Java, which is better known as ludruk by the community.

Besides ludruk, there is also a traditional theater art that has developed in Indonesian society, ketoprak. The famous Ketoprak originates from the Central Java area. But along with the development of the era, ketoprak also develops anywhere in all regions of Indonesia. According to the research results of the Art Section of the Cultural Service (Art Division of the Directorate General of Culture), ketoprak was created in Central Java, more precisely in Surakarta, in 1908 by RMT Wreksodiningrat. The name ketoprak also comes from the name of a tiprak musical instrument (a type of bamboo musical instrument used to repel birds in the fields) (Saptomo 1996).

Ketoprak has a long history. Herry Lisbijanto describes the periods of ketoprak as it evolved. The first is the ketoprak Gejog or Lesung period in 1887-1908. Initially, this art was a type of play by village youths to joke around during the full moon by singing traditional Javanese songs or dolanan songs and was accompanied by sounds that came from lesung. Second was the Wreksadiningrat ketoprak period from 1908-1925. A royal servant of the Surakarta Hadiningrat palace named KRMT H Wreksadiningrat worked on this ketoprak art to turn it into the pride of palace art. The third is the Wreksatama ketoprak period from 1925-1927 when a new ketoprak group was 
established outside the palace standing in Madyataman Surakarta. It was founded by Ki Wisangkara (a former member of the Wreksadiningrat ketoprak group). The fourth is the Krida Madya Utama period of 1927-1930 which was a ketoprak group founded on the wishes of the community itself. The fifth is the Gardanela ketoprak period from 1930 to 1955 which was the ketoprak period that experienced many novelties in the form of stories, costumes, and so forth. The sixth is the modern ketoprak period from 1955-1958. This ketoprak period was often referred to as the ketoprak tobong, because it often changed the performance location. The last one was the Ketoprak Gaya Baru period in 1958-1987. There were many innovations from ketoprak artists in this period to attract the public's interest to watch ketoprak performances (Lisbijanto 2013).

Based on the description above, which briefly explains the traditional theater arts, namely ludruk and ketoprak, the two traditional theater types have almost no differences. One of the examples lies in the stories that are being told, which both taking stories from everyday life (Saptomo 1996). However, there is a little difference between the play's meaning in the performance of ludruk and ketoprak. Another supporting aspect is the use of language during performances. Ludruk and ketoprak often use colloquial language or languages from the area of origin, for example, using Javanese, Madurese, or other languages.

\subsection{Ketoprak Rukun Karya and its development in Sumenep}

Sumenep is an area that has several cultures and arts that must be preserved. Some of the arts in the Sumenep Regency include building art, sports, dance, drama and puppetry (Prawirodiningrat 1986). Mr. Tajul Arifin (2020), who is a cultural observer and the Head of the Cultural Heritage of Sumnep Regency, Madura, East Java, also explains that there is quite a lot of culture and art in the Sumenep Regency. One of them is culture and also art from the heritage of the Sumenep Palace. Ketoprak is a traditional theater and drama or puppetry that continues to develop in Sumenep Regency, Madura, East Java. The Madurese community is more familiar with the Madura ketoprak as loddrok. Before being known as loddrok, this performance was known as ajhing (Santoso 2016). As supported by Mr. Tajul Arifin (2020), before being called loddrok, this art's name was ajhing. Ajhing is one of the performances that bring a prayer of goodness played by a group of men and accompanied by a saronen orchestra, which is staged from village to village and is followed by jokes about daily life taken from the story of One Thousand and One Nights (Bouvier 2002).

Two ketoprak groups that are still active in Madura are the Rukun Famili and the Rukun Karya ketoprak groups. Ketoprak in Madura has existed since Dutch rule era. However, at that time, it was still known as ajhing. In relation to Madura's traditional theater arts, there are two terms that are often used, namely ketoprak and loddrok or ludruk (Sayono, et al. 2020). The Madurese community and some writers often use the term loddrok or ludruk instead of using the term ketoprak to refer to these two traditional theater groups in Madura. This is because, according to research, the term "ketoprak" is not included in the Madurese language, unlike ludruk, which later became loddrok (Bouvier 2002). Then around the 1970s loddrok ketoprak appeared during Yogyakarta's official seminar on ketoprak in 1977.

According to Mr. Encung Hariadi (2020), as the director of the Rukun Karya ketoprak, it has been in Sumenep since 1949. Three ketopraks already existed at that time, including the ketoprak Banjir Dunia, Bintang Massa and Rukun Muda (Hariadi 2020). In the 1960s, a number of loddrok had also existed, namely Jata Kemala (from the village of Juruan Daya in Batuputih), Karya Kemala (from Juruan Laok) and then Loddrok Karya Putra was born (Bouvier 2002). Some of these loddrok groups still play ajhing in their performances. According to Bouvier (2002), the Madurese loddrok was inspired by elements of old ajhing jokes: word play, mimicing, bodybuilding and black and white makeup. The difference between ketoprak and loddrok, according to the loddrok group from Batuputih, can be seen in the clothes used, such as the king's loddrok who wears a long-sleeved shirt while in ketoprak, they are bare-chested and only wear jewelry (Bouvier 2002).

Since the time of Dutch rule, there have been ketopraks in Madura. One of them is the Rukun Santoso group from Tanjung Village, Sumenep Regency, East Java. At that time, the performances were still straightforward, done without decorations, only playing for the village people and in the 


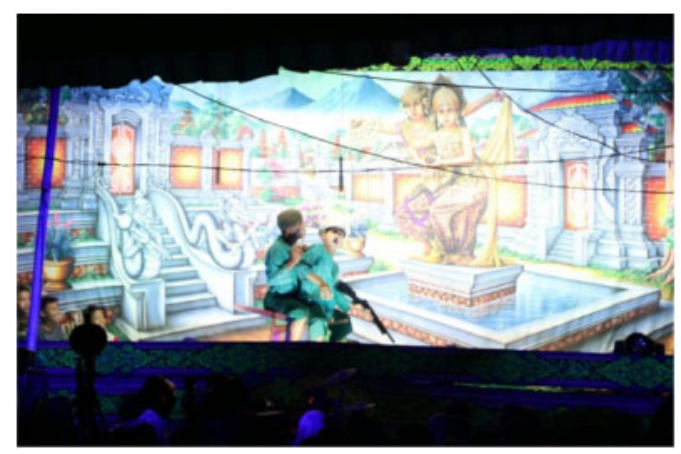

Figure 1. Ketoprak Rukun Karya performance.

form of a play, not ketoprak (Bouvier 2002). Close to the independence era, around 1943, the name Rukun Santoso was changed to Rukun Famili and switched from theatrical to ketoprak (Bouvier 2002). The Rukun Famili group also uses accompanying music with gamelan instruments. It can be said that the Rukun Famili ketoprak group marked the beginning of the birth of other ketoprak groups in Sumenep Regency, Madura, East Java. In 1975, a member of the Rukun Famili group went to do an internship at the Siswo Budoyo ketoprak group for one month. At the end of 1975, the Rukun Famili ketoprak group was split into two groups, namely the Rukun Famili and the Rukun Karya, and applied the knowledge that had been acquired during an internship at Siswo Budoyo in 1977 (Bouvier 2002).

Ketoprak Rukun Karya was born in 1975 and began to develop around 1976 as a fraction of the Rukun Famili ketoprak group. According to Mr. Encung Hariadi (2020), as the director of the Rukun Karya ketoprak group, the Rukun Karya ketoprak was born in 1976, while the name Rukun Karya was taken because at that time Golkar Party was popular (Golongan Karya). Based on the results of an interview with Mr. Encung Hariadi (known as Mr. Jaka Linglung), who is currently serving as the director of ketoprak Rukun Karya, at the beginning of the show, to promote the ketoprak, they still used tickets to watch the ketoprak performance. Currently, the Ketoprak Siswo Budoyo from Tulungaggung has joined the Ketoprak Rukun Karya for about a month. Its director since 1994, Mr. Encung, explains that a director in ketoprak Madura has to be really positive because the audience assessed and researched what is delivered in the ketoprak show. In the early days of the Madura ketoprak, which was around the 20th century, the narrative model during the performance had to be truly pure in presenting a story, be it historical stories, legends or everyday life. Then around the 21st century, from 2007 to 2008, during the Rukun Karya ketoprak show, they slipped in a little joke before telling the story. Similar to the stories presented in general ketoprak's, the Rukun Karya ketoprak also brings historical stories such as the history of Sumenep or Pamekasan, Majapahit, Walisongo, and others.

Figure 1 shows a sequence of a comedy scene from Rukun Famili ketoprak performances in 2020. During this Rukun Karya ketoprak performance, the local language of Maduranese is often used. The use of regional languages is also a special characteristic of ketoprak or ludruk performances in various regions. In Madura the ketoprak show can also be staged in various conditions. For example, it is held in public places using tickets, for private ceremonies such as weddings, and for spiritual events or at sacred graves (Bouvier 2002). In performances at weddings, the Rukun Karya ketoprak starts at 23.00 and runs to 03.00 in the morning. Before that, Javanese repertoire in the form of a set of gamelan was already heard.

As is well known, several traditional arts, including theater, music, dance, and others, have declined due to changing times. It cannot be denied that the decline in public interest in watching traditional theater was one of the triggers for the collapse of the art theater (Spiller 2012). Therefore, the Rukun Karya ketoprak originating from Saronggi, Sumenep Regency, Madura, East Java is 
struggling to maintain its existence. There are several things that make the Rukun Karya ketoprak group survive, such as their name that has been well known among the Madurese community even in other areas such as in East Java and West Java, their form of an organization, and the existence of AD/ART (Articles of Association/Budget Household) (Hariadi 2020).

\subsection{The development of traditional theater arts in the modern era}

At present, the types of theater in Indonesia are increasingly developing following the changing times. Some traditional theaters are no longer visited by Indonesians - consequently, several other theaters were born, known as modern theaters in Indonesia. The modern theater has different characteristics from traditional theater. In modern theater the presented stories prioritize western theater aesthetics or dramaturgy, where performances are held in a special place (the proscenium stage) and the audience has to pay an entrance ticket. While it functions only as entertainment, the story is told more on the topic of contemporary events, and the usual language used is Indonesian (Zaini 2015). However, at the present time, traditional theater also tries its best to survive. Therefore, several modern theater groups have remodeled some of their performance elements to make them more interesting and less boring. One example is traditional theater, such as ketoprak.

Currently, the lighting on the ketoprak show is awe-inspiring. In fact, due to good lighting, the ketoprak show is no longer perceived as traditional theater but has become a modern theater. Not only that, other traditional theaters such as ketoprak, ludruk, and wayang have also begun to be packaged in cassette format, broadcast on radio and television. This shows the traditional theaters' persistence in maintaining their existence by keeping up with the changing times. Even though there have been developments in terms of performances, the contents of stories presented by traditional theater such as ketoprak still use royal stories, legends and still contain moral messages.

In general, ketoprak has also undergone changes and developments from time to time. First, it can be seen from the musical instruments used to accompany the ketoprak show. Initially, the ketoprak accompaniment music used a mortar, but now it uses Javanese gamelan. Second, it can be seen from the stories that are delivered, the beginning of the establishment of ketoprak only brings stories of everyday life until later it also delivers royal stories, histories, legends and so forth. Another prominent change is observed in the development of ketoprak costumes. At first, the costumes used were only everyday clothes, but when the ketoprak had developed royal stories in their performances, the costumes used were adjusted to the ones that were to be played. In addition, the stage for the performance has also changed; the backdrop used has been filled with lighting and depicts an atmosphere such as a palace, forest, garden, and so forth (Lisbijanto 2013). It can be seen in Figure 1 that illustrates the performance of Rukun Karya ketoprak in 2020. In the photo, the backdrop used is beautiful and matches the background of the presented story.

In the 1980s-1990s the art of ketoprak grew with new innovations. During those years, a ketoprak, which was commonly called ketoprak plesetan existed (Lisbijanto 2013). In this type of ketoprak, performance is packaged more loosely, and the characters played more varied. Besides that, the addition of humor to the show is also a development in ketoprak (Hatley 1971; Peacock 1967). In 1995, the art of ketoprak also grew, which showed its comedic function, namely the ketoprak humor tradition (Lisbijanto 2013). This Ketoprak is usually performed on national television with not many ketoprak players. Some of the innovations that grew in the 1990s-2000s has helped ketoprak to survive (Sunardi 2011)

\section{CONCLUSION}

Along with the development of the era, traditional theater almost disappeared in Indonesian society. Public engagement is an essential factor in the survival of conventional theater. The decreasing public interest in watching or maintaining the art will indirectly erase traditional theater. Modern theaters have developed a lot in Indonesia. Therefore, traditional theater groups carry out various reformations or innovations to survive in the modern era, like ketoprak, which currently adds jokes 
before the story begins. Not only that, but the stage part has also been arranged in a more modern way in order to captivate the ketoprak audience. The addition of lighting and stage backdrops has also been adjusted to the story's background to attract the audience's attention. Therefore, apart from the need for innovations from traditional theater artists, the public is also an essential factor that can maintain the existence of traditional theaters in Indonesia.

\section{REFERENCES}

Azali, K. 2012. Ludruk: Masihkah Ritus Modernisasi?. Lakon: Jurnal Kajian Sastra dan Budaya, 1(1).

Bouvier, H. 2002. Lebur: Seni Musik dan Pertunjukan dalam Masyarakat Madura. Bogor: Mardi Yuana Graphic Printing.

Cohen, M. 2013. Anthologizing Indonesian Popular Theatre. Asian Theatre Journal, 30(2), 506-519. Retrieved December 1, 2020, from http://www.jstor.org/stable/43187275

Hatley, B. 1971. Wayang and Ludruk: Polarities in Java. The Drama Review: TDR, 15(2), 88-101. doi: $10.2307 / 1144625$

Heryanto, A. 1982. Teater di Indonesia. Basis, November.

Lisbijanto, H. 2013. Ketoprak. Yogyakarta: Graha Science.

Peacock, J. 1967. Comedy and Centralization in Java: The Ludruk Plays. The Journal of American Folklore, 80(318), 345-356. doi:10.2307/537413

Peters, R. 2016. Death and the Control of Life in an Indonesian City. Bijdragen Tot De Taal-, Land- En Volkenkunde, 172(2/3), 310-342. Retrieved December 1, 2020, from http://www.jstor.org/stable/44325706

Prawirodiningrat, SI. 1986. Sepintas Kilas Adat Budaya Sumenep Sebagai Aspek Pembangunan Nyata. Sumenep: Solar Offset Printing.

Rahayu, F. 2014. Perkembangan Seni Pertunjukan Ludruk di Surabaya Tahun 1980-1995 (Tinjuan Historis Grup Kartolo CS). Avatara, Volume 2, No. 2.

Ridhoi, R. 2018. Melihat Motif Pendidikan Di Nusantara Dari Perspektif Historis. Jurnal Pendidikan Sejarah Indonesia, 1(2), 135-149. Retrieved from http://www.jurnalpsi.com/index.php/jpsi/article/view/15

Samidi. 2006. Teater Tradisional di Surabaya1950-1965: Relasi Masyarakat dan Rombongan Seni. Humanities, vol. 18 , No. 3 .

Santoso, M. 2016.Transformasi Bentuk Tari Srimpi dalam Pembukaan Loddrok Rukun Famili di kabupaten Sumenep-Madura. From (Jurnalmahasiswa.unesa.ac.id, accessed on 06 September 2020).

Saptomo. 1996. Sejarah dan Perkembangan Ketoprak dalam Kehidupan Masyarakat Modern. Education Horizons, Number 2.

Sayono, J, et al. 2020. Dari Ajhing Hingga Ketoprak: Perjalanan Historis Kesenian Ludruk di Sumenep Madura Sejak 1940-an. Malang: Java Creative.

Spiller, H. 2012. How Not to Act like a Woman: Gender Ideology and Humor in West Java, Indonesia. Asian Theatre Journal, 29(1), 31-53. Retrieved December 1, 2020, from http://www.jstor.org/stable/23359543

Sunardi, C. 2011. Negotiating Authority and Articulating Gender: Performer Interaction in Malang, East Java. Ethnomusicology, 55(1), 32-54. doi:10.5406/ethnomusicology.55.1.0031

Weintraub, A.N., 2010. Dangdut stories: a social and musical history of Indonesia's most popular music. Oxford University Press.

Zaini, M. 2015. Pembelajaran Seni dan Teater untuk Siswa. College Students, and the Public. Yogyakarta: Frame Publishing.

Encung Hariadi (38 y.o.), interviewed on August 29, 2020.

Tajul Arifin (58 y.o.), interviewed on 31 August 2020.

Zawawi Imron (75 y.o.), interviewed on July 18, 2020. 